Єніна Анастасія. Митне регламентування порушень митних правил та відповідальності за їх порушення. Інститут бухгалтерського обліку, контроль та аналіз в умовах глобалізації. 2020. Випуск 1. С. 19-28.

DOI: https://doi.org/10.35774/ibo2020.01.019

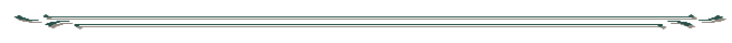

\author{
УДК 351.713:336.244 \\ JEL Classification G28, H30, K23
}

\title{
Єніна Анастасія
}

д.ф., доцент кафедри митної справи і оподаткування

Харківський національний економічний університет імені Семена Кузнеця

м. Харків, Україна

E-mail: anastasiyaenina1308@gmail.com

ORCID: 0000-0003-2307-7003

\section{МИТНЕ РЕГЛАМЕНТУВАННЯ ПОРУШЕНЬ МИТНИХ ПРАВИЛ ТА ВІДПОВІДАЛЬНОСТІ ЗА ЇХ ПОРУШЕННЯ}

\footnotetext{
Анотація

Bcтуn. Cтаття присвячена дослідженню явищ порушення митних правил які спостерігаються у широкому маситабі і розелядаються вже на світовому рівні, а не тільки на рівні однієї держави. Для подолання їх негативного впливу та поширення всі держави докладають багато зусиль, розробляючи і реалізуючи окремі завдання, програми, вдосконалюючи своє законодавство і практику боротьби з порушеннями.

Методи. Методологічною основою дослідження стали бібліографічний метод - для дослідження літературних джерел для отримання необхідної інформації щодо теми дослідження; метод аналізу та синтезу для вивчення об'єкта та предмета дослідження та комплексного дослідження проблемного питання порушення митних правил; метод спостереження - для з'ясування сутності митних правопорушень; абстрактно-логічний метод - для теоретичного узагальнення та формування відповідних висновків; граффічний метод - для візуалізації класифрікації митних правопорушень та елементів складу суб'єктивної сторони митних правопорушень; метод критичного аналізу та системного підходу - для дослідження особливостей настання адміністративної відповідальності. Для проведення дослідження була використана спеціальна література за обраною тематикою, кодисіковані законодавчі акти, які відображають певну тематику роботи, праці вчених, пов'язані з порушенням митних правил, також були проаналізовані статті та точки зору митних експертів на зазначену проблему.

Результати. Проведено аналіз сутності порушень митних правил. Розкрито ознаки складу митних правопорушень у відповідності до Митного кодексу України (об'єкт, суб'єкт, об'єктивна сторона та суб'єктивна сторона правопорушення). Розглянуто класифікацію порушень митних правил за ступенем завданої шкоди. Надано характеристику адміністративної відповідальності за порушення митного законодавства із зазначенням суб'єктів, які можуть бути притягнуті до адміністративної відповідальності. Розкрито ознаки адміністтративної відповідальності за порушення митних правил. Наведено сутнісну та класифікаційну характеристику адміністративних стягнень за порушення митних правил, таких як попередження, штрафр, конффіскація, розглянуто особливості застосування кожного виду адміністративних стягнень. Розглянуто види порушень митних правил, їх класифікація за певними ознаками у відповідності до Митного кодексу України. Розглянуто обставини, за яких виключається настання адміністративної відповідальності.

Перспективи. Перспективи подальших досліджень полягають у дослідженні питань встановлення чітких відмінностей порушень митних правил від контрабанди. Та дослідження питань настання відповідальності за контрабанду.

Ключові слова: порушення митних правил, склад митних правопорушень, класифікація порушень митних правил, адміністративна відповідальність за порушення митних правил, адміністративні стягнення за порушення митних правил.
} 
Вступ.

На даному етапі розвитку України, все частіше виноситься на розгляд суспільства поняття відповідальності. У митному праві відповідальність $€$ наслідком вчиненого правопорушення. Тобто, це означає порушення митних правил. Відповідно, відповідальністю за порушення митних правил $є$ обов'язок особи, яка їх порушила, понести наслідки особистого і матеріального характеру, відповідно до норм Митного кодексу України.

Сьогодні явища контрабанди та порушення митних правил спостерігаються у широкому масштабі і розглядаються вже на світовому рівні, а не тільки на рівні однієї держави. Для подолання їх негативного впливу та поширення всі держави докладають багато зусиль, розробляючи і реалізуючи окремі завдання, програми, вдосконалюючи своє законодавство і практику боротьби 3 порушеннями. Як і будь-якій іншій державі, в Україні наявні масштаби порушень митних правил та контрабанди вражають своїми обсягами та багатогранністю здійснення. Такі масштаби правопорушень спонукають силові структури та органи центральної виконавчої влади шукати нові методи боротьби з цими явищами.

\section{Аналіз останніх досліджень та публікацій.}

Проблематика протидії контрабанді та іншим видам правопорушень у митній сфері привертає до себе значну увагу як вчених, так і практиків. Зокрема, контрабанда та порушення митних правил розглядалися у справах О.П. Дячкіна [1], М.М. Дороша [2]. Питаннями дослідження особливостей адміністративної відповідальності за порушення митних правил займались такі вчені А.І. Крисоватий [6], В.В. Ченцов [3], В.В. Сидоренко [10], К.І. Садікова [10], Г. Галочка [5]. У праці О.О. Зотенко [9] розглянуто класифікацію митних правопорушень. Питаннями боротьби 3 порушеннями митних правил та запобіганням таких порушень приділяли увагу О.В. Серих [10], В.Я. Настюк [11], М.Г. Шульга [11]. Зазначені вчені у свої працях звертали увагу на основні причини митних правопорушень та на їх сутність, відмінність від контрабанди, особливостей настання адміністративної відповідальності та її видів.

\section{Мета.}

Головною метою роботи є дослідження видів та класифікацій порушень митних правил, а також особливостей настання адміністративної відповідальності за порушення митного законодавства.

\section{Методологія дослідження.}

Методологічною основою дослідження стали різноманітні загальнонаукові та спеціальні методи дослідження та пізнання. А саме: бібліографрічний метод - для дослідження літературних джерел для отримання необхідної інформації щодо теми дослідження; метод аналізу та синтезу для вивчення об'єкта та предмета дослідження та комплексного дослідження проблемного питання порушення митних правил; метод спостереження - для з'ясування сутності митних правопорушень; абстрактно-логічний метод - для теоретичного узагальнення та формування відповідних висновків; графічний метод - для візуалізації класифікації митних правопорушень та елементів складу суб'єктивної сторони митних правопорушень; метод критичного аналізу та системного підходу - для дослідження особливостей настання адміністративної відповідальності. Для проведення дослідження була використана спеціальна література за обраною тематикою, кодифіковані законодавчі акти, які відображають певну тематику роботи, праці вчених, пов'язані з порушенням митних правил, також були проаналізовані статті та точки зору митних експертів на зазначену проблему. 


\section{Результати.}

Основним завданням митних органів кожної держави $є$ забезпечення митної безпеки. А отже, саме митні органи повинні забезпечити дотримання митного законодавства, надходження до державного бюджету мита та інших митних платежів, запобігати ввезення в країну заборонених і небезпечних товарів, а також приймати міри щодо захисту вітчизняного товаровиробника [1].

Регламентує сукупність суспільних відносин у митній сфері - митне законодавство. Саме за допомогою норм митного законодавства встановлюється відповідальність за певні митні правопорушення. До митних правопорушень відносяться злочини у митній ссрері, порушення встановлених митних правил та порушення які перешкоджають виконанню повноважень та посадових обов'язків , які покладені на посадових осіб митних органів Державної митної служби [2].

Порушення митних правил поділяються за критеріями в залежності від суспільної небезпеки, яка виражається у наявності або відсутності тяжких наслідків які настали через діяння, розмірі майнової шкоди, часі та способі вчинення правопорушення [3, ст. 201].

У відповідності до ст. 458 Митного кодексу України (МКУ) порушення митних правил $є$ адміністративним правопорушенням, яке являє собою протиправні, винні (умисні або 3 необережності) дії чи бездіяльність, що посягають на встановлений МКУ та іншими актами законодавства України порядок переміщення товарів, транспортних засобів комерційного призначення через митний кордон України, пред'явлення їх митним органам для проведення митного контролю та митного оформлення, а також здійснення операцій 3 товарами, що перебувають під митним контролем або контроль за якими покладено на митні органи МКУ чи іншими законами України, і за які МКУ передбачена адміністративна відповідальність [4].

Ознаки складу порушення митних правил об'єднуються в чотири групи (елементи), що характеризують:

- об'єкт порушення митних правил;

- об'єктивну сторону порушення митних правил;

- суб'єкт порушення митних правил;

- суб'єктивну сторону порушення митних правил [5].

Усі ці елементи складу порушення митних правил нерозривно поєднані між собою. Наявність цих елементів обов'язкова для кваліфікації конкретного діяння як порушення митних правил. Якщо хоч би один з них відсутній або не відповідає тим властивостям, які передбачені відповідною нормою МКУ, то зазначене діяння не є порушенням митних правил (рис. 1).

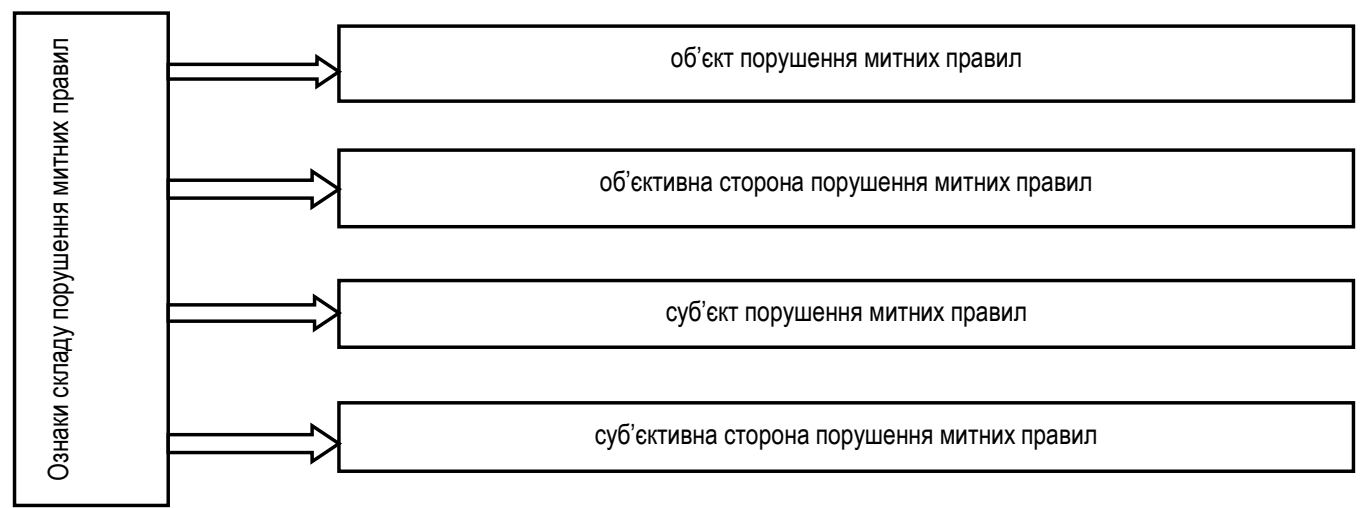

\section{Рис. 1. Ознаки складу порушення митних правил [5]}

Зазначені ознаки характеризують відношення особи до вчинення правопорушення, ставлення особи до правопорушення, розуміння наслідків своїх дій чи бездіяльності, 
характеристики особи правопорушника, спрямованість його дій або необережність, його психологічне ставлення до своїх дій або бездіяльності.

Розглянемо більш детально кожний елемент складу порушення митних правил.

Об'єкт порушення митних правил - це те, на що саме спрямоване посягання. Це суспільні відносини, яким в результаті посягання особою може бути завдана шкода, або задається шкода. Такі відносини охороняються законом.

Об'єктивна сторона порушення митних правил - це система передбачених нормою митного права ознак, що характеризують зовнішню сторону проступку. Об'єктивна сторона включає в себе передусім такі основні складові, як: протиправне діяння (дія чи бездіяльність), суспільно шкідливі наслідки та причинно-наслідковий зв'язок між діянням та його шкідливими наслідками. Так, наприклад, порушення суб'єктами зовнішньоекономічної діяльності митних правил може знаходити свій зовнішній вираз у різноманітних діяннях: відправлення без дозволу митного органу транспортного засобу, що перебуває під митним контролем, пошкодження пломб, печаток чи інших засобів митного забезпечення або нез'явлення за встановленою формою точних відомостей про товари, транспортні засоби. Наслідками таких діянь можуть бути: уникнення від сплати мита та митних платежів або зменшення їх розміру. Варто мати на увазі, що діяння повинно знаходитись у причинно-наслідковому зв'язку з шкідливими наслідками, яке воно спричинило.

Встановити такий причинно-наслідковий зв'язок - означає з'ясувати обставини виникнення шкідливих наслідків, визначити, чи настали вони в результаті скоєння протиправного діяння, чи внаслідок іншого, як дане діяння вплинуло на розмір цих наслідків [7].

Суб'єкт порушення митних правил - можуть бути громадяни, які скоїли шкідливе діяння або бездіяльність, а також посадові особи підприємств, установ та організацій. У тому разі, коли суб'єктом розглядається громадянин (громадянин України, особа без громадянства, громадянин іншої держави) обов'язковою умовою є досягнення ним на момент скоєння діяння 16-річного віку.

Під посадовими особами у відповідних статтях Кодекс України про адміністративні правопорушення (КУАП) [8] признаються працівники, що знаходяться на державній або суспільній службі і ті, хто займає посади, пов'язані із здійсненням організаційно-владних, адміністративноуправлінських фрункцій, внаслідок яких виникають певні правові наслідки для осіб і організацій, яким вони адресовані. Щоб визначити коло цих осіб, необхідно звернутися до аналізу чинного законодавства, яке визначає правовий статус працівників органів державної виконавчої влади, адміністрації державних установ і підприємств, а також органів управління (адміністрації), громадських організацій (об'єднань). Згідно з п.43 ст.4 МКУ [4], посадові особи підприємств - це керівники та інші працівники підприємств (резиденти та нерезиденти), які в силу постійно або тимчасово виконуваних ними трудових (службових) обов'язків відповідають за додержання вимог, встановлених МКУ, законами та іншими нормативно-правовими актами України, а також міжнародними договорами України, укладеними у встановленому законом порядку [7].

Суб'єктивна сторона порушення митних правил - це особисте ставлення суб'єкта правопорушення до його дій чи бездіяльності, характеризує його психологічне сприйняття порушення, розуміння наслідків діяння та навмисності або необережності діяння.

Суб'єктивна сторона порушень митних правил характеризується психічним ставленням особи до вчинення правопорушення [5] (рис. 2):

Порушення митних правил можна вважати діянням за необережністю, якщо особа, яка скоїла правопорушення, могла передбачити можливі негативні наслідки своїх діянь або бездіяння, але розраховувало на їх запобігання або не передбачувала можливих наслідків, хоча повинна була їх передбачувати [6, с. 403]. Умисне ж вчинення митного правопорушення передбачає що особа, яка його вчинила у повному обсязі усвідомлювала настання можливих негативних наслідків та хотіла їх настання та усвідомлювала протиправність своїх дій або бездіяння.

За митні правопорушення передбачена адміністративна відповідальність, та деякі види порушень караються відповідно до Кримінального кодексу України. 


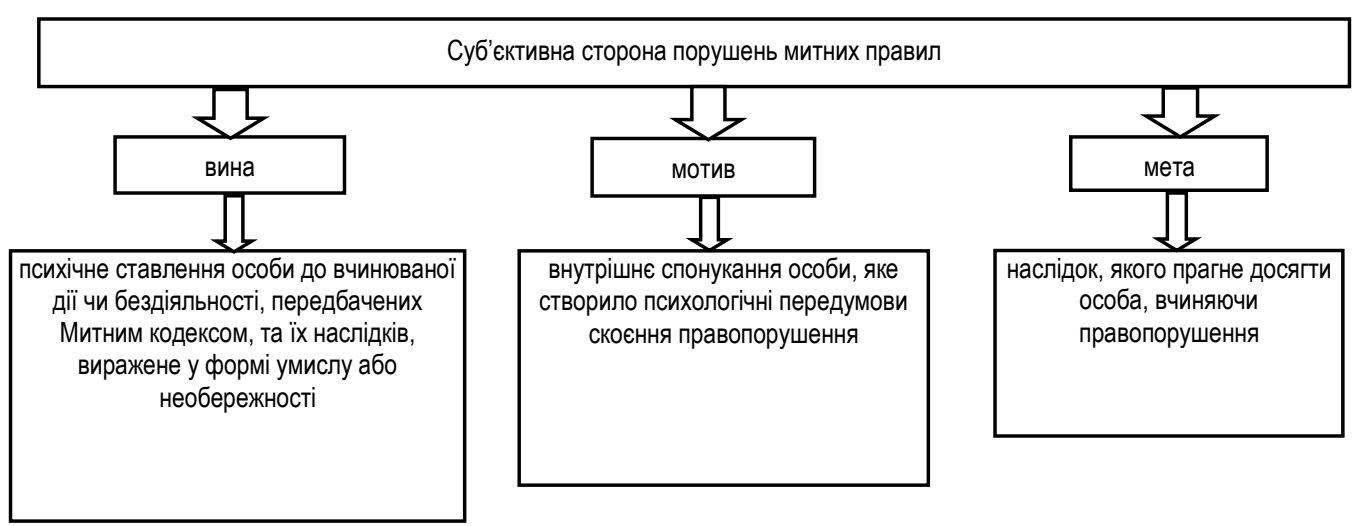

\section{Рис. 2. Суб'єктивна сторона порушень митних правил [5]}

В науковій літературі порушення митних правил поділяється за певними ознаками. Класифікація порушень митних правил має не тільки теоретичне, але й практичне значення. Досить поширеною $€$ класифікація порушень митних правил за ступенем завданої шкоди. Відповідно до цього критерію їх поділяють на [2] (рис. 3):

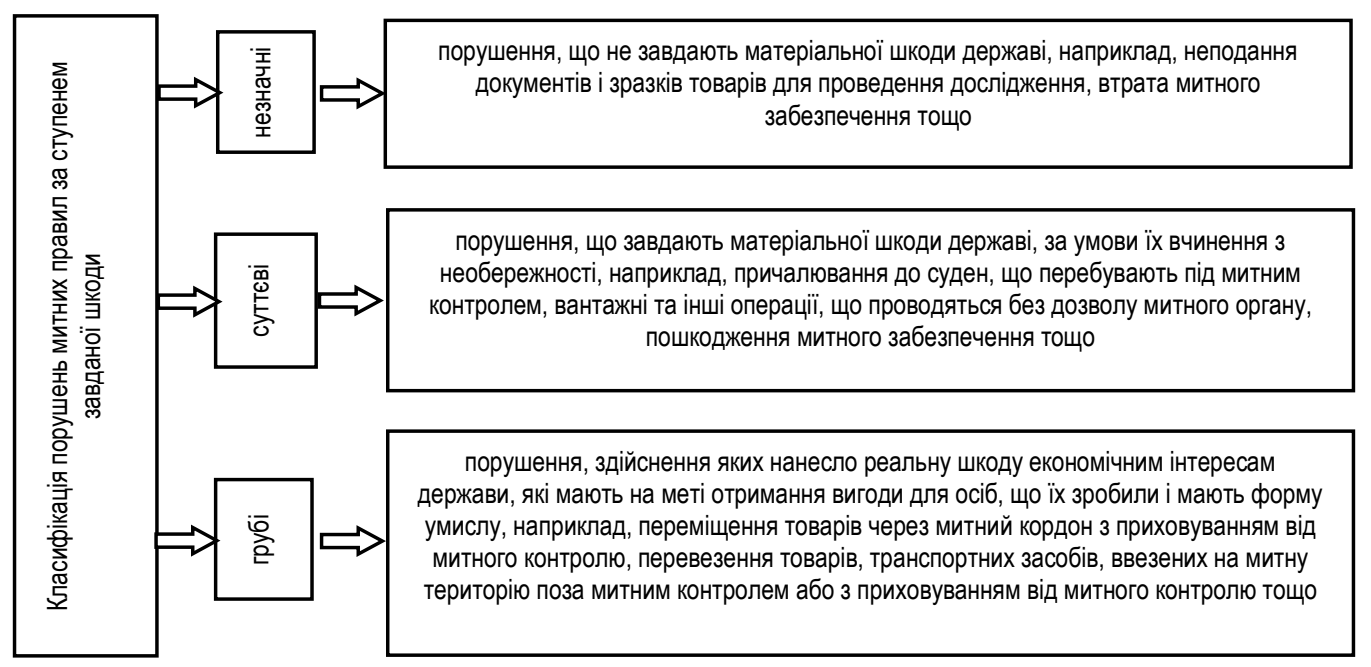

\section{Рис. 3. Класифікація порушень митних правил за ступенем завданої шкоди [2]}

До адміністративної відповідальності за порушення митних правил відносяться адміністративні стягнення за митні правопорушення. Відповідно до МКУ [4] вони можуть застосовуватись у вигляді:

1) попередження. Дане адміністративне стягнення виноситься у формі постанови про накладення адміністративного стягнення стосовно недопустимості таких діянь у майбутньому;

2) штраф. Дане адміністративне стягнення полягає у покладенні на особу, яка притягується до адміністративної відповідальності за правопорушення, обов'язку сплатити до державного бюджету грошові кошти у сумі, яка визначається МКУ залежно від виду та характеру вчиненого правопорушення. Необхідно звернути увагу, що сплата штрафу, якщо при цьому не 
застосовується адміністративне стягнення у вигляді конфіскації товарів, не звільняє особу, яка вчинила порушення митних правил, від сплати митних платежів, крім випадків, передбачених МКУ.

3) конфіскація товарів, транспортних засобів комерційного призначення - безпосередніх предметів порушення митних правил, товарів, транспортних засобів із спеціально виготовленими сховищами (тайниками), що використовувалися для приховування товарів - безпосередніх предметів порушення митних правил від митного контролю (крім транспортних засобів комерційного призначення, які використовуються виключно для перевезення пасажирів і товарів через митний кордон України за визначеними маршрутами та рейсами, що здійснюються відповідно до розкладу руху на підставі міжнародних договорів, укладених відповідно до закону), а також транспортних засобів, що використовувалися для переміщення товарів - безпосередніх предметів порушення митних правил через митний кордон України поза місцем розташування митного органу [4]. Конфіскація як адміністративне стягнення за порушення митних правил полягає у примусовому вилученні товарів, транспортних засобів і безоплатній передачі їх у власність держави. При цьому моторні транспортні засоби та несамохідні транспортні засоби, що буксируються ними, розглядаються як самостійні об'єкти конфіскації. Варто зазначити, що конфіскація може бути застосована лише у разі наявності рішення суду. Крім того, конфіскація, як адміністративне стягнення може бути застосована незалежно від того, чи є ці товари, транспортні засоби власністю особи, яка вчинила правопорушення.

Необхідно зазначити, що адміністративні стягнення поділяються на основні та додаткові. Наприклад, як основні адміністративні стягнення можуть бути застосовані попередження та штраф. А конфіскація товарів, про які йшла мова вище, може бути і як основним так і додатковим адміністративним стягненням. При цьому варто зауважити, що у відповідності до МКУ [4] за одне і те саме порушення митних правил може накладатися тільки основне або основне і додаткове адміністративні стягнення. А в тому разі, якщо відповідальність передбачається у вигляді основного й додаткового стягнення, то застосування лише додаткового, без основного, не допускається, за певним виключенням. (рис. 4).

Митні експерти [9] класифікують митні порушення, зазначені у МКУ, за певними критеріями

Адміністративна відповідальність за порушення митних правил закріплюється правовими нормами, що містяться в МКУ. Як елемент митно-правової норми, адміністративна відповідальність є каральною санкцією [3, с. 210].

Адміністративну відповідальність, як правило, пов'язують із застосуванням заходів адміністративного примусу. Але серед великої кількості заходів адміністративно-примусового характеру (митний контроль, адміністративне затримання, вилучення товарів і документів тощо) тільки адміністративні стягнення виконують функцію покарання і тільки їх застосування спричинює настання адміністративної відповідальності [10].

Відповідно до ст. 522 МКУ справи, про порушення митних правил, які передбачено статтями 468, 469, 470, 474, 475, 477, 478, 479, 480, 481, 485 МКУ, розглядаються митними органами.

Справи про порушення митних правил, які передбачено статтями 471, 472, 473, 476, 482, 483, 484 МКУ, а також усі справи про порушення митних правил, вчинені особами, які не досягли 18-річного віку, розглядаються місцевими судами (суддями).

Тобто всі справи про порушення митних правил, за які передбачено відповідальність у вигляді конфіскації, розглядаються судами.

Адміністративно-карні посягання на митні правила належать до розряду найбільш шкідливих діянь. Розкриваючи визначення адміністративної відповідальності за порушення митних правил, слід сказати, що вона передбачає винність двоякого роду. По-перше, обов'язок винної особи дати звіт про свої неправомірні діяння у ссрері відносин митної справи 
(адміністративна відповідальність пов'язана 3 поверненням до минулого, 3 обов'язком відзвітуватися за минулу поведінку й пояснити митному органу причини невиконання норм митного законодавства); по-друге, обов'язок понести покарання у вигляді адміністративного стягнення (означає, що за порушення митних правил особа зобов'язана понести передбачене законом покарання у вигляді адміністративного стягнення, тобто підлягає певним обмеженням у межах санкцій митного законодавства) [10].

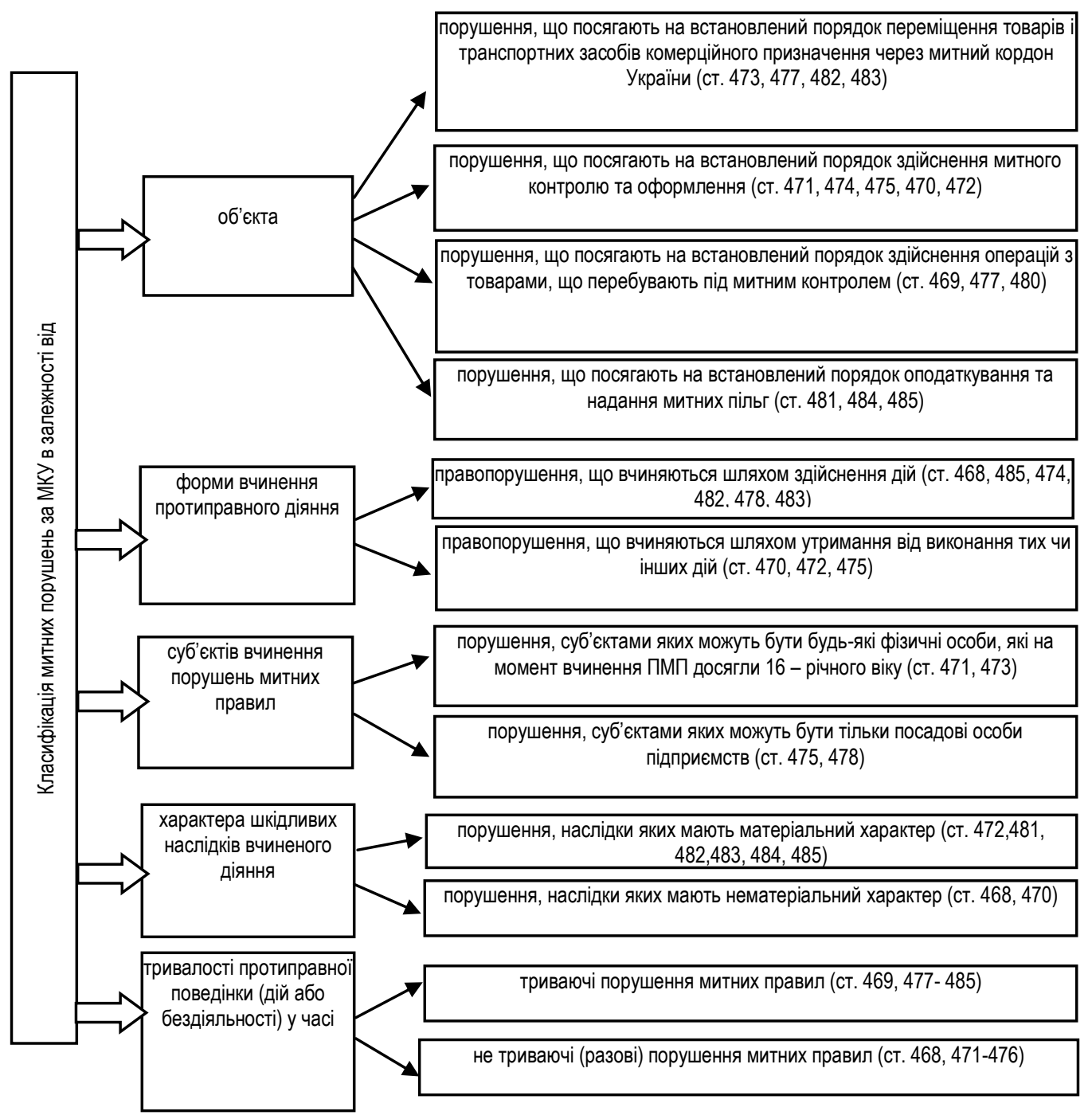

\section{Рис. 4. Класифікація митних порушень за МКУ [4]}

Адміністративна відповідальність за порушення митних правил має свої ознаки:

- адміністративно-карані порушення митних правил, на відміну від інших адміністративних правопорушень, передбачені лише МКУ;

- має більш конкретні цілі - вона спрямована на відносини у сфері митної справи України, охорону митних правил, а також виховання поваги до цих правил і правовідносин, що регулюються 
ними у сфрері митної справи України з боку всіх учасників митних відносин;

- може наставати тоді, коли правопорушник виявлений на території іншої держави і, при наявності державних угод чи договорів між митними органами суміжних держав, про сумісний контроль;

- внаслідок аварії або дії непереборної сили відповідальність не настає за вчинення лише деяких правопорушень, передбачених МКУ, якщо такі факти підтверджуються відповідними документами;

- суб'єктами застосування адміністративної відповідальності виступає система митних органів, серед яких повноваження по накладанню стягнень чітко розмежовані, та суди;

- за порушення митних правил застосовується лише три види адміністративних стягнень попередження, штраф, конфіскація;

- предмети порушення митних правил підлягають конфіскації незалежно від часу вчинення або виявлення такого порушення [11, с. 69].

Обставинами, що виключають відповідальність за порушення митних правил є такі:

1. Крайня необхідність. Не є адміністративним правопорушенням дія, яка хоч і передбачена МКУ, але вчинена у стані крайньої необхідності, тобто для усунення небезпеки, яка загрожує громадському порядку, власності, правам і свободам громадян, установленому порядку управління, якщо ця небезпека за даних обставин не могла бути усунута іншими засобами і якщо заподіяна шкода є менш значною, ніж відвернена шкода.

2. Необхідна оборона. Не є адміністративним правопорушенням дія, яка хоч і передбачена МКУ, але вчинена у стані необхідної оборони, тобто при захисті громадського порядку, власності, прав і свобод громадян, установленого порядку управління від протиправного посягання шляхом заподіяння тому, хто посягає, шкоди, якщо при цьому не було допущено перевищення меж необхідної оборони. Перевищенням меж необхідної оборони визнається явна невідповідність захисту характеру й суспільній шкідливості посягання.

3. Неосудність. Не підлягає адміністративній відповідальності особа, яка під час вчинення протиправної дії чи бездіяльності була в стані неосудності, тобто не могла усвідомлювати свої дії або керувати ними внаслідок хронічної душевної хвороби, тимчасового розладу душевної діяльності, слабоумства чи іншого хворобливого стану [8, с. 17-20].

\section{Висновки і перспективи.}

Одним із найбільш дієвих засобів забезпечення ефективної діяльності митної справи та митної політики, в цілому, виступає адміністративна відповідальність за порушення митних правил, яка у свою чергу, допомагає в укріпленні законності та посиленні прав і свобод громадян. Слід зауважити, що застосування адміністративної відповідальності, а саме адміністративних санкцій, у діяльності митних органів, сприяє поліпшенню нормальних умов для здійснення підприємницької діяльності в Україні. Адже накладення адміністративних стягнень сприяє підвищенню рівня правосвідомості суб'єктів господарювання, учасників митних правовідносин, виховує негативне відношення до порушників митних правил, і інших законів взагалі, має профілактичний ефект та запобігає порушенням митних правил.

Проведений аналіз особливостей застосування адміністративної відповідальності за порушення митних правил дозволяє зробити висновок, що окремі правові норми потребують подальшого удосконалення. Варто враховувати, що законодавчі норми стосовно регламентації митних правил особливо потребують змін та доповнення, через те, що виникають нові суспільні відносини у митній сфері, які тепер започатковуються на принципах демократії, правової держави та гуманізму. Актуальним вважається питання неврегульованості нормами МКУ адміністративної відповідальності за митні правопорушення, адже така відповідальність регулюється Кодексом України про адміністративні правопорушення.

Вважається за необхідне внесення змін до МКУ відносно відображення відповідальності за 
митні правопорушення, а також надання митним органам права здійснювати оперативнорозшукову діяльність стосовно порушення норм митного права. Такі зміни будуть сприяти посиленню відповідальності за порушення митних правил та підвищенню ефективністю запобігання таких правопорушень.

\title{
Список використаних джерел
}

1. Дячкін О. П. Суспільна небезпечність контрабанди і правова відповідальність за її вчинення. Форум права. 2012. № 1. С. 281-288.

2. Дорош М. М. Порушення митних правил в Україні. Науковий вісник ЛНУВМБТ ім. С.З. Гжицького. 2013. № 1. C. $66-69$.

3. Митне право України / за ред. В. В. Ченцова. Київ, 2007. 283 с.

4. Митний кодекс України. URL: https://zakon.rada.gov.ua/laws/show/4495-17

5. Адміністративна відповідальність за порушення митних правил. URL: http://www.visnuk.com.ua/ua/pubs/id/7355

6. Митна справа / за ред. А. І. Крисоватого. Тернопіль : ВПЦ «Екон. Думка ТНЕУ», 2014. 540 с.

7. Порушення митних правил та відповідальність за них URL: https://wiki.legalaid.gov.ua/index.php/\%D0\%9F\%D0\%BE\%D1\%80\%D1\%83\%D1\%88\%D0\%B5\%D0\%BD\%D0\%BD \%D1\%8F_\%D0\%BC\%D0\%B8\%D1\%82\%D0\%BD\%D0\%B8\%D1\%85_\%D0\%BF\%D1\%80\%D0\%B0\%D0\%B2\%D0\% B8\%D0\%BB_\%D1\%82\%D0\%B0_\%D0\%B2\%D1\%96\%D0\%B4\%D0\%BF\%D0\%BE\%D0\%B2\%D1\%96\%D0\%B4\%D 0\%B0\%D0\%BB\%D1\%8C\%D0\%BD\%D1\%96\%D1\%81\%D1\%82\%D1\%8C_\%D0\%B7\%D0\%B0_\%D0\%BD\%D0\%B8 $\% \mathrm{D} 1 \% 85$

8. Кодекс України про адміністративні правопорушення. URL: https://zakon.rada.gov.ua/laws/show/80731-10

9. Класифікація порушень митних правил. критерії розмежування «триваючих» та «разових» ПМП. URL: $\quad$ http://dspace.onua.edu.ua/bitstream/handle/11300/6766/\%D0\%97\%D0\%BE\%D1\%82\%D0\%B5\%D0\% $\mathrm{BD} \% \mathrm{D} 0 \% \mathrm{BA} \% \mathrm{D} 0 \% \mathrm{BE}$. .pdf?sequence=1\&isAllowed=y

10. Сєрих О. В. Боротьба з контрабандою та порушеннями митних правил. Митна безпека. 2014. № 2. C. $95-101$.

11. Сидоренко В.В., Садікова К.І. Адміністративна відповідальність за порушення митних правил, Науковий вісник Ужгородського національного університету, 2014, Випуск 24, Том 3.

12. Настюк В.Я., Шульга М.Г. Митне право України. Харків : Нац. юрид. акад. України, 2005. 114 с.

Статтю отримано: 22.12.2019 / Рецензування 30.01.2020 / Прийнято до друку: 20.03.2020

\author{
Anastasiia Yenina \\ Ph.D. (in Economics), Associate Professor \\ Department of Customs Affairs and Taxation \\ Simon Kuznets Kharkiv National University of Economics \\ Kharkiv, Ukraine \\ E-mail: anastasiyaenina1308@gmail.com \\ ORCID: 0000-0003-2307-7003
}

\section{CUSTOMS REGULATIONS OF CUSTOMS RULES AND RESPONSIBILITY FOR THEIR VIOLATION}

\footnotetext{
Abstract

Introduction. The article is aimed at researching the violation of customs rules which are observed in a wide scale and examined already at world level, but not only at the level of one state. All states make efforts for overcoming of them negative influence and distribution, developing and implementing separate tasks, programs, perfecting the legislation and practice of fight against violations.

Methods. The methodological basis of the study was a variety of general scientific and specific methods of research and cognition. Namely: bibliographic method - for the study of literary sources to obtain the necessary information on the topic of research; method of analysis and synthesis - to study the object and subject of research and comprehensive study of the problem of violation of customs rules; surveillance method - to find out the nature of customs offenses; abstract and logical method - for theoretical generalization and formation of relevant conclusions; graphical method - to visualize the
} 
classification of customs offenses and elements of the composition of the subjective side of customs offenses; method of critical analysis and systematic approach - to investigate the features of the onset of administrative responsibility. Special research literature on the selected topic was used for the study, codified leqislative acts reflecting a specific topic of work, scientists' work related to violation of customs rules, articles and points of view of customs experts on the mentioned problem were also analyzed.

Results. The analysis of essence of violations of customs rules is conducted by the author. The signs of composition of custom offences are exposed in accordance with the Custom code of Ukraine (object, subject, objective side and subjective side of offence). Classification of violations of customs rules is considered on the degree of the inflicted harm. Description of administrative responsibility for violation of customs legislation with pointing of subjects that can be attracted to administrative responsibility is given. Signs of administrative responsibility for violation of customs rules are revealed. Essence and classification description of administrative penalties for violation of customs rules, such as warning, fine, confiscation, the features of application of every type of administrative penalties are considered. The types of violations of custom rules are considered, their classification on certain signs in accordance with the Custom code of Ukraine. Circumstances at that the offensive of administrative responsibility is eliminated are considered.

Discussion. Prospects for further research are to investigate the establishment of clear differences between violations of customs requlations from smuqgling. And research on the issue of liability for smuqqling

Keywords: violation of customs rules, composition of customs offences, classification of violations of customs rules, ad ministrative responsibility for violation of customs rules, administrative penalties for violation of customs rules.

\section{Referenses}

1. Djachkin, O. P. (2012). Suspil'na nebezpechnist' kontrabandy i pravova vidpovidal'nist' za i'i' vchynennja [Public danger of smuggling and legal responsibility for its commission]. Forum prava [Forum right], 1, 281-288. [in Ukr.]

2. Dorosh, M. M. (2013). Porushennja mytnyh pravyl v Ukrai'ni [Violation of customs rules in Ukraine]. Naukovyj visnyk LNUVMBT im. S. Z. Gzhyc'kogo [Scientific Bulletin of LNUVMBT. S. Z. Gzitsky], 1, 66-69. [in Ukr.]

3. Chencova, V. V. (Ed.). (2007). Mytne pravo Ukrai'ny [Customs law of Ukraine]. Kyi'v.

4. Mytnyj kodeks Ukrai'ny. (n.d.) Retrieved from: https://zakon.rada.gov.ua/laws/show/4495-17

5. Administratyvna vidpovidal'nist' za porushennja mytnyh pravyl. Retrieved from: http://www.visnuk.com.ua/ua/pubs/id/7355

6. Krysovatyi, A. I. (Ed.). (2014). Mytna sprava. [Customs]. Ternopil': VPC «Ekon. Dumka TNEU».

7. Porushennja mytnyh pravyl ta vidpovidal'nist' za nyh. Retrieved from: https://wiki.legalaid.gov.ua/index.php/\%D0\%9F\%D0\%BE\%D1\%80\%D1\%83\%D1\%88\%D0\%B5\%D0\%BD\%D0\%BD\% D1\%8F_\%D0\%BC\%D0\%B8\%D1\%82\%D0\%BD\%D0\%B8\%D1\%85_\%D0\%BF\%D1\%80\%D0\%B0\%D0\%B2\%D0\%B8 \%D0\%BB_\%D1\%82\%D0\%B0_\%D0\%B2\%D1\%96\%D0\%B4\%D0\%BF\%D0\%BE\%D0\%B2\%D1\%96\%D0\%B4\%D0\%B 0\%D0\%BB\%D1\%8C\%D0\%BD\%D1\%96\%D1\%81\%D1\%82\%D1\%8C_\%D0\%B7\%D0\%B0_\%D0\%BD\%D0\%B8\%D1\% 85

8. Kodeks Ukrai'ny pro administratyvni pravoporushennja. Retrieved from: https://zakon.rada.gov.ua/laws/show/80731-10

9. Klasyfikacija porushen mytnyh pravyl. kryterii rozmezhuvannja «tryvajuchyh» ta «razovyh» PMP. Retrieved from: http://dspace.onua.edu.ua/bitstream/handle/11300/6766/\%D0\%97\%D0\%BE\%D1\%82\%D0\%B5\% D0\%BD\%D0\%BA\%D0\%BE.pdf?sequence=1\&isAllowed=y

10. Sjeryh, O. V. (2014). Borot'ba z kontrabandoju ta porushennjamy mytnyh pravyl [Combating smuggling and violations of customs rules]. Mytna bezpeka [Customs security], 2, 95-101. [in Ukr.]

11. Sydorenko, V.V. \& Sadikova, K.I. (2014). Administratyvna vidpovidal'nist' za porushennja mytnyh pravyl [Administrative responsibility for violation of customs rules]. Naukovyj visnyk Uzhgorods'kogo nacional'nogo universytetu [Scientific Bulletin of Uzhgorod National University], 24, T. 3. Retrieved from: https://dspace.uzhnu.edu.ua/jspui/bitstream/lib/7093/1/\%D0\%90\%D0\%B4\%D0\%BC\%D1\%96\%D0\%BD\%D1\%96\%D1 \%81\%D1\%82\%D1\%80\%D0\%B0\%D1\%82\%D0\%B8\%D0\%B2\%D0\%BD\%D0\%B0\%20\%D0\%B2\%D1\%96\%D0\%B4\% D0\%BF\%D0\%BE\%D0\%B2\%D1\%96\%D0\%B4\%D0\%B0\%D0\%BB\%D1\%8C\%D0\%BD\%D1\%96\%D1\%81\%D1\%82\%D 1\%8C \%20\%D0\%B7\%D0\%B0\%20\%D0\%BF\%D0\%BE\%D1\%80\%D1\%83\%D1\%88\%D0\%B5\%D0\%BD\%D0\%BD\%D1 \%8F\%20\%D0\%BC\%D0\%B8\%D1\%82\%D0\%BD\%D0\%B8\%D1\%85\%20\%D0\%BF\%D1\%80\%D0\%B0\%D0\%B2\%D0\% B8\%D0\%BB.pdf [in Ukr.] akad. Ukrai'ny.

12. Nastjuk, V.Ja. \& Shulga, M.G. (2005). Mytne pravo Ukrai'ny [Customs law of Ukraine]. Harkiv: nac. juryd. 